\title{
ANALISIS PENGARUH PUBLIC RELATION TERHADAPCUSTOMER LOYALTY YANG DIMODERASI OLEH BRAND IMAGE PADA SMARTPHONE "X"
}

\author{
Lily Suhaily \\ Elias \\ Fakultas Ekonomi Universitas Katolik Indonesia Atma Jaya, Jakarta \\ Jl. Jend. Sudirman no.51,Jakarta Selatan. Telp. 021-5708815 \\ Email :lily.suhaily@atmajaya.ac.id
}

\begin{abstract}
Development of technology today is higly increased, especially communication tecnology. Based on this fenomenon, many companies have opportunity to build-up smartphone. This conditions will increased competition between the company. To win the competitions, company must promote their smartphone by using public relation. According that conditions, this research evaluate the influence of public relation to customer loyalty which moderated by brand image. 160 questionnares were distributed to on 26 Mei 2014 untill 1 July 2014by using random sampling. The result shows that public relation influences customer loyalty which moderated by brand image.
\end{abstract}

Keywords: technology communicatioan, public relation, customer loyalty and brand image

Perkembangan teknologi terus melesat seiring perkembangan zaman. Halini membuka peluang bagi para pebisnis dalam memasarkan produk-produk berteknologi tinggi, terutama perkembangan teknologi komunikasi yang telah melalui perubahan yang cukup signifikan dari tiap generasi. Terbukti dengan banyaknya bermunculan perangkat telekomunikasi dengan teknologi canggih.

Kemunculan teknologi telekomunikasi yang canggih ini juga didorong oleh kebutuhan manusia untuk menghadapi kompleksnya berbagai masalah yang dihadapi dan perlu diselesaikan dalam waktu cepat dan singkat. Terlebih lagi saat ini konsumen dimudahkan dengan hadirnya smartphone atau telepon pintar. Smartphone ini merupakan telepon genggam yang mempunyai kemampuan tingkat tinggi, dan mempunyai fungsi yang hampir sama dengan komputer. Tentunya banyak sekali fitur-fitur yang diberikan oleh smartphone sehingga saat ini banyak sekali peminatnya. Jika awalnya pengguna smartphone ini adalah para pejabat atau karyawan swasta, wanita karir juga eksekutif muda, kini pengguna smartphone sudah menyentuh berbagai kalangan masyarakat dan berbagai segmen masyarakat.

Kesempatan ini digunakan oleh banyak perusahaan untuk berlomba memasarkan produk smartphone mereka dan memberikan banyak kemudahan bagi konsumen yang menggunakannya. Perusahanperusahaan harus menggunakan berbagai macam strategi untuk memasarkan produk smartphone mereka, dan salah satunya dengan menggunakan strategi public relation. Public relation kini telah menjadi alat komunikasi yang mempunyai peran yang lebih besar, selain dalam membangun citra perusahaan, public relation juga mempunyai peran dalam menaikkan citra produk dan merek perusahaan mereka serta dapat menciptakaan loyalitas konsumen terhadap produk tersebut (Haris dan Hallen, 2006:20).

Salah satu produk smartphone yang sudah terkenal di dunia adalah produk "X". Produk "X" terus berusaha mencari peluang dalam mengkomunikasikan keunggulan brandnya secara persuasif agar dapat meningkatkan kredibilitas produk di mata pelanggannya. Selain melakukan promosi pemasaran melalui media iklan produk "X" juga menggunakan alat promosi yang penting yaitu public relation. Yang dimana alat promosi ini menggunakan biaya yang lebih murah dibandingkan promosi melalui iklan tetapi mempunyai peran dalam membangun brand. Dengan menggunakan alat promosi public relation maka diharapkan dapat menciptakan consumer loyalty terhadap produk smartphone "X". Tentu brand image juga menjadi salah satu faktor penting yang mendukung public relation dalam memasarkan produknya agar 
dapat tercipta kesetiaan konsumen. Penelitian ini bertujuan untuk mengetahui pengaruh public relation terhadap customer loyalty yang dimoderasi oleh brand image padaprodukSmartphone "X".

\section{Brand Image}

Brand image adalah apa yang konsumen pikirkan dan rasakan ketika mendengar atau melihat nama suatu merek (Hsieh \& Li, 2007). Atau dengan kata lain, citra merek merupakan bentuk atau gambaran tertentu dari suatu jejak makna yang tertinggal di benak pikiran konsumen, yang kemudian menuntun pikiran konsumen tersebut untuk bersikap terhadap merek, apakah akan mencoba lalu menjadi setia atau sekadar mencoba lalu pergi, atau sama sekali tidak ingin mencoba karena citra yang buruk atau tidak relevan dengan kebutuhan konsumen.

Selanjutnya, brand image merupakan keseluruhan persepsi terhadap suatu merek yang dibentuk dengan memproses informasi dari berbagai sumber setiap waktu (Kotler \& Keller, 2008). Selain itu, brand image adalah sekumpulan asosiasi merek yang terbentuk dan melekat dibenak konsumen (Rangkuti, 2008). Citra merek (brand image) memiliki beberapa fungsi, di antaranya sebagai pintu masuk pasar (market entry), sumber nilai tambah produk (source of added product value), penyimpan nilai perusahaan (corporate store of value), dan kekuatan dalam penyaluran produk (channel power) (Kotler \& Keller, 2008).

Salah satu strategi yang paling populer untuk meningkatkan citra merek adalah melalui aliansi merek (brand alliance). Sebuah aliansi merek dapat digambarkan sebagai hubungan jangka pendek atau panjang atau kombinasi atribut berwujud (tangibles) dan tidak berwujud (intangibles) yang terkait dengan mitra merek. Salah satu tipe paling populer dari aliansi merek adalah kemitraan co-brand. Co-branding dapat didefinisikan sebagai penempatan dua nama merek pada satu produk atau paket (Nickels \& McHugh alih bahasa Maulana (2008).

Fungsi citra merek adalah sebagai sumber nilai tambah produk (source of added product value). Para pemasar mengakui bahwa citra merek tidak hanya merangkum pengalaman konsumen dengan produk dari merek tersebut, tapi benar-benar dapat mengubah pengalaman itu. Sebagai contoh, konsumen terbukti merasa bahwa makanan atau minuman dari merek favorit mereka memiliki rasa yang lebih baik dari kompetitor jika diuji secara unblinded dibandingkan jika diuji secara blinded taste tests. Dengan demikian citra merek memiliki peran yang jauh lebih kuat dalam menambah nilai produk dengan mengubah pengalaman produk (Rangkuti 2008).

Nama merek dengan citra yang kuat berfungsi baik sebagai indikator maupun kekuatan dalam saluran distribusi (channel power). Ini berarti merek tidak hanya berperan penting secara horizontal, dalam menghadapi pesaing mereka, tetapi juga secara vertikal, dalam memperoleh saluran distribusi dan memiliki kontrol dan daya tawar terhadap persyaratan yang dibuat distributor (Kotler \& Keller alih bahasa Molen, 2008:360).

\section{Consumer Loyalty}

Terciptanya kepuasan dapat memberikan beberapa manfaat diantaranya hubungan antara perusahaan dan pelanggan menjadi harmonis, menjadi dasar bagi pembelian ulang dan menciptakan loyalitas pelanggan serta rekomendasi dari mulut ke mulut yang menguntungkan perusahaan (Kotler \& Keller alih bahasa Molan, 2008). Selain itu, loyalitas pelanggan merupakan sebuah jasa dari suatu perusahaan yang menyertakan aspek perasaan didalamnya, khususnya yang membeli secara teratur dan berulang-ulang dengan konsistensi yang tinggi, namun tidak hanya membeli ulang suatu barang dan jasa, tetapi juga mempunyai komitmen dan sikap yang positif terhadap perusahaan yang menawarkan produk jasa tersebut (Hsieh \& Li, 2007).

Tingkatan loyalitas menurut Griffin alih bahasa Yahya, 2003, adalah: (1) Suspects, Meliputi semua orang yang akan membeli barang perusahaan. Disebut suspect karena yakin bahwa mereka akan berbuat tetapi belum tahu apapun mengenai perusahaan, barang dan jasa yang ditawarkan. (2) Prospects, Orang-orang yang memiliki kemampuan untuk membeli. Para prospect ini meskipun mereka belum melakukan pembelian, mereka telah mengetahui keberadaan perusahaan, barang dan jasa yang ditawarkannya. (3) Disqualified prospec, adalah prospect yang mengetahui keberadaan barang dan jasa tetapi tidak mempunyai kebutuhan dan kemampuan untuk membeli, disini konsumen sudah mengetahui harga atau tarif dari barang dan jasa yang ditawarkan. (4) First time customer (pelanggan pemula), Konsumen yang membeli pertama kali, mereka masih menjadi konsumen dari produk dan jasa pesaing. (5) Repeat customer (pelanggan berulang), konsumen yang telah melakukan pembelian berulang suatu produk sebanyak dua kali 
atau lebih, biasanya produk yang sama. (6) Client (pelanggan tetap), konsumen yang membeli semua produk yang ditawarkan dan berlangsung lama, yang membuat mereka tidak terpengaruh oleh tarikan pesaing lain. (7) Advocates (penganjur), seperti halnya clients, advocates membeli barang dan jasa yang ditawarkan dan yang mereka butuhkan, serta melakukan pembelian secara teratur, selain itu mereka mendorong teman-temannya agar membeli barang dan jasa perusahaan tersebut pada orang lain, dengan begitu secara tidak langsung mereka telah melakukan pemasaran untuk perusahaan dan membawa konsumen untuk perusahaan.

\section{Public Relations}

Public relations adalah membangun hubungan baik dengan berbagai masyarakat perusahaan dengan memperoleh publisitas yang diinginkan, membangun citra perusahaan yang baik, dan menangani atau menghadapi rumor, cerita, dan kejadian yang tidak menyenangkan (Kotler \& Armstrong). Menurut Kotler \& Armstrong (alih bahasa Sabran, 2008), dalam perusahaan, divisi pulic relations bisa melaksanakan satu atau semua fungsi berikut ini: (1) Hubungan pers atau agen pers dengan menciptakan dan menempatkan informasi berharga di media untuk menarik perhatian pada seseorang, produk, atau jasa. (2) Publisitas produk, mempublikasikan produk tertentu. (3) Kegiatan masyarakat, membangun dan mempertahankan hubungan masyarakat secara umum dan mayarakat lokal. (4) Melobi yaitu membangun dan mempertahankan hubungan dengan pembuat peraturan dan pejabat pemerintah untuk mempengaruhi undang-undang dan peraturan. (5) Hubungan Investor yakni mempertahankan hubungan dengan pemegang saham dan pihak lainnya dalam komunitas keuangan. (5)Pengembangan yaitu mengembangkan hubungan dengan anggota organisasi nirlaba untuk mendapatkan dukungan finansial atau sukarela.

Menurut Kotler \&Keller (2008:264): "Public relationsrelate to a variety of programs and are designed to promote or protect a company's image or its individualproducts. Publicrelations may also include annual reports, fund-raising and membership drives, lobbying, special event management, and public affairs. Bagi pemasar global, membangun hubungan yang baik dengan berbagai pihak yang berkepentingan seperti karyawan, pers, distributor, kosumen, pemerintah merupakan bagian yang penting dari strategi komunikasi.
Sehubungan dengan hal ini, pemasar perlu menggunakan strategi promosi dalam bentuk public relation. Public relationsterdiri dari pengelolaan yang terdiri dari aliran informasiantara satu organisasi dengan masyarakat (Kotabe dan Helsen, 2011:456).

\section{Kerangka Penelitian}

Dalam penelitian ini terdapat tiga variabel laten yang akan diteliti. Variabel yang pertama adalah public relations yang berkedudukan sebagai variabel bebas (independent variable). Variabel kedua adalah citra merek (brand image) sebagai variabel moderator (moderating variable). Variabel ketiga adalah loyalitas konsumen (customer loyalty) yang berkedudukan sebagai variabel tidak bebas atau terikat (dependent variable).

Berdasarkan variabel-variabel yang diteliti, model penelitian ini adalah:

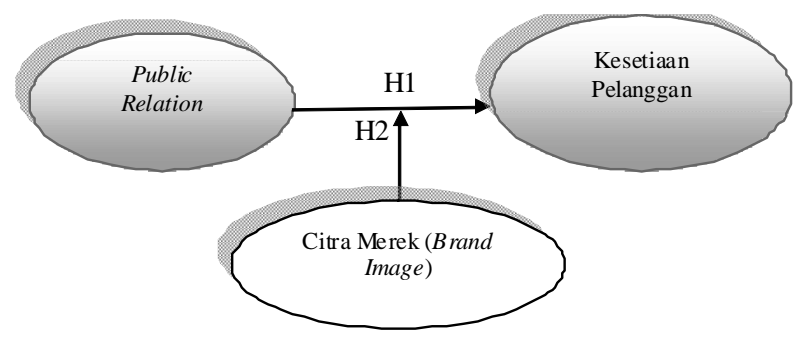

Bagan 1. Model Penelitan

\section{Hipotesis Konseptual}

H1: Public relation mempunyai pengaruh terhadap loyalitas konsumen (customer loyalty).

$\mathrm{H} 2$ : Public relation mempunyai pengaruh terhadap loyalitas konsumen (customer loyalty) yang dimoderasi oleh brand image

\section{METODE}

Dalam mengumpulkan data, penulis menyebarkan kuesioner kepada customeryang pernah membeli Smartphone merek "X" di sebuah perkumpulan keagamaan, dengan menggunakan metode random sampling. Random sampling dilakukan dengan cara mengocok bulan dari April sampai Desember tahun 2014. Bulan yang muncul adalah bulan Mei, dan Juli 2014. Selanjutnya penulis mengocok lagi bulan Mei dan Juli 2014. Untuk bulan Mei keluar minggu kedua dan empat.yaitu tanggal 11 Mei dan minggu keempat tanggal 25 Mei. Sedangkan untuk bulan Juli keluar minggu ketiga yaitu tanggal 20 Juli dan minggu keempat tanggal 27 Juli. Jumlah kuesioner yang disebarkan 160 karena menurut Hair, et al. (2006:373), jika 
ukuran populasi tidak terukur, dalam menentukan ukuran sampel didasarkan pada rasio antara 1 banding 10 untuk maksimal atau 1 dibanding lima untuk minimal sehingga berdasarkan teori tersebut jumlah kuesioner yang disebarkan adalah 160 (jumlah indikator dikalikan 10 yaitu 16 x $10=160$ ).
Skala pengukuran data yang digunakan adalah skala likert lima tingkat, yaitu: sangat setuju (5), setuju (4), cukup setuju (3), tidak setuju (2), dan sangat tidak setuju(1).Setelah data diperoleh, dilakukan uji validitas dan uji reliabilitas. Tingkat validitas diukur dengan korelasi pearson moment. Skala pengukuran yang

Tabel 1. Definisi Operasional Variabel

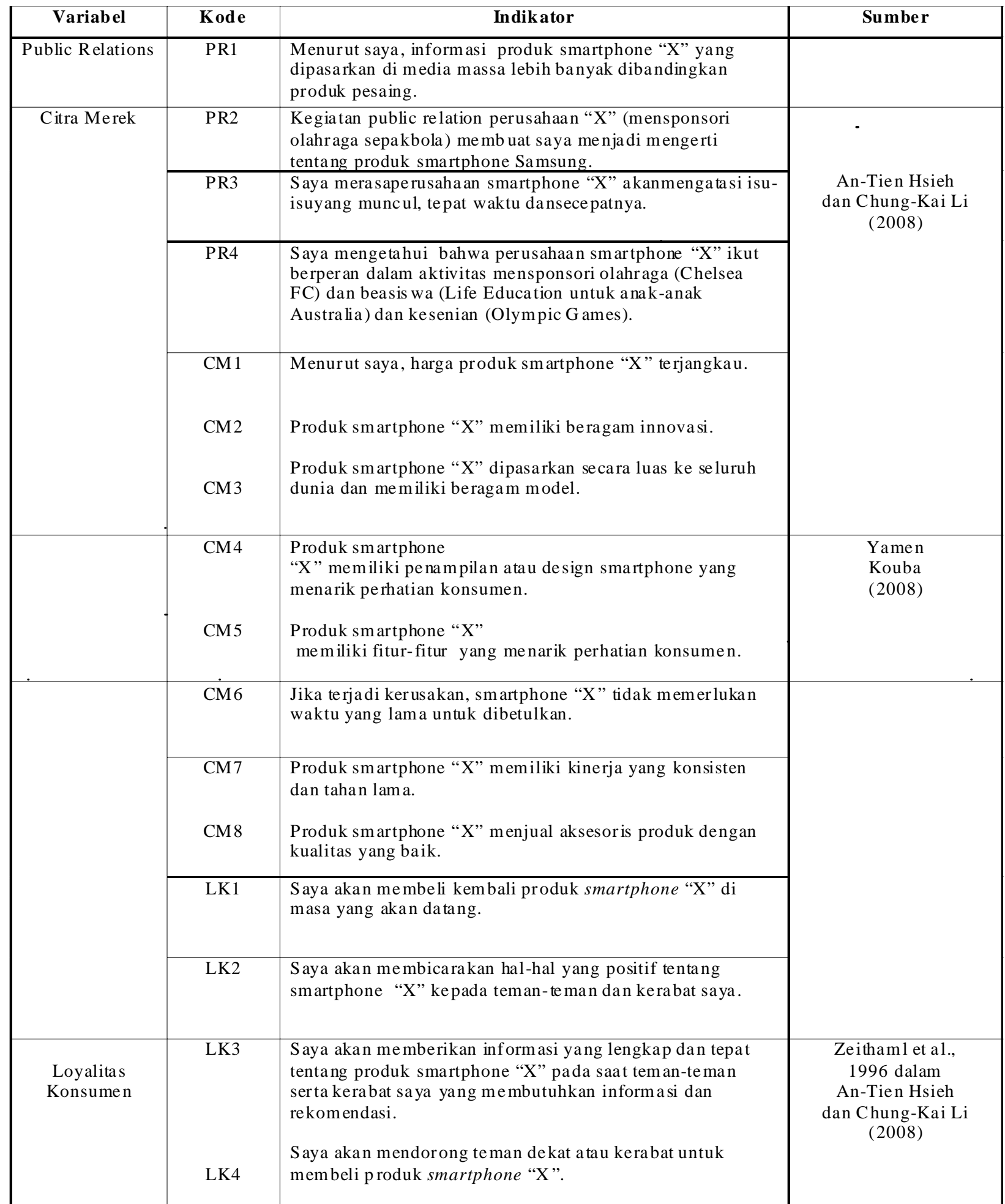


reliabel sebaiknya memiliki nilai Alpha Cronbach minimal 0,70 (Nunnally, 1978; Nunnaly dan Bernstein, 1994 dalam Uyanto 2006). Uji statistik yang akan digunakan adalah analisis regresi moderasi.

\section{HASIL DAN PEMBAHASAN}

\section{Uji Validitas dan Reliabilitas}

Untuk menguji validitas, digunakan korelasi pearson momen dengan mengambil 30 data yang telah diperoleh. Hasil validitas dapat dilihat pada tabel 2 dan hasil uji reliabilitas dapat dilihat pada tabel 3.
Berdasarkan tabel 2, diperoleh nilai signifikansi di bawah 0,05 , artinya indikator-indikator public relations, brand image dan customer loyalty adalah valid.

Berdasarkan tabel 3, dapat dikatakan bahwa indikator-indikator public relations, brand image dan customer loyalty reliabel karena nilai cronbach alpha > 0.70 (Ghozali, 2011:47).

\section{Karateristik Responden}

Berdasarkan tabel 4, diketahui kebanyakan responden adalah berjenis kelamin pria, usia 26-35 tahun,

Tabel 2. Uji Validitas Indikator-Indikator Variabel Public Relation, Brand Image, dan Customer Lo-yalty

\begin{tabular}{|c|c|c|c|}
\hline Kode & Indikator & Nilai Sig. & Keterangan \\
\hline \multicolumn{4}{|c|}{ V ariabel Public Relation } \\
\hline PR1 & $\begin{array}{l}\text { Menurut saya,Informasi tentang produk "X" yang dipasarkan dimedia lebih } \\
\text { banyak dibandingkan produk kompetitor. }\end{array}$ & 0.000 & $<0.05$, Valid \\
\hline PR2 & $\begin{array}{l}\text { Saya merasa kegiatan public relationperusahaan "X" (mensponsori olahraga } \\
\text { sepakbola) membuat saya menjadi mengerti tentang produk smartphone" } \mathrm{X} \text { " }\end{array}$ & 0.000 & $<0.05$, Valid \\
\hline PR3 & $\begin{array}{l}\text { Saya merasabahwa perusahaan smartphone"X" akanmengatasi isu-isu yang } \\
\text { muncul, tepat waktu dansecepatnya. }\end{array}$ & 0.000 & $<0.05$, Valid \\
\hline PR4 & $\begin{array}{l}\text { Saya mengetahui bahwa perusahaan smartphone"X" ikut berperan dalam } \\
\text { aktivitas mensponsori olahraga (Chelsea FC) dan beasiswa (Life Education } \\
\text { untuk anak-anak Australia) dan kesenian (Olympic Games). }\end{array}$ & 0.000 & $<0.05$, Valid \\
\hline \multicolumn{4}{|c|}{ Variabel Brand Image } \\
\hline BI1 & Menurut saya, harga produk smartphone“ $\mathrm{X}$ " terjangkau. & 0.000 & $<0.05$, Valid \\
\hline $\mathrm{BI} 2$ & Produk smantphone"X" memiliki beragam innovasi. & 0.000 & $<0.05$, Valid \\
\hline $\mathrm{BI} 3$ & $\begin{array}{l}\text { Produk smartphone"X" dipasarkan secara luas ke seluruh dunia dan } \\
\text { memilki beragam model smartphone. }\end{array}$ & 0.000 & $<0.05$, Valid \\
\hline BI4 & $\begin{array}{l}\text { Produk smartphone "X" memiliki penampilan atau designsmartphone yang } \\
\text { menarik perhatian konsumen. }\end{array}$ & 0.000 & $<0.05$, Valid \\
\hline BI5 & Produk smantphone"X" memiliki fitur-fitur yang menarik. & 0.006 & $<0.05$, Valid \\
\hline BI6 & $\begin{array}{l}\text { Jika terjadi kerusakan, smartphone"X" tidak memerlukan waktu yang lama } \\
\text { untuk dibetulkan. }\end{array}$ & 0.000 & $<0.05$, Valid \\
\hline $\mathrm{BI} 7$ & Produk smantphone "X" memiliki kinerja yang konsisten dan tahan lama & 0.000 & $<0.05$, Valid \\
\hline BI8 & $\begin{array}{l}\text { Produk smartphone "X" menjual aksesoris produk dengan kualitas yang } \\
\text { baik. }\end{array}$ & 0.024 & $<0.05$, Valid \\
\hline \multicolumn{4}{|c|}{ Variabel Customer Loyalty } \\
\hline CL1 & $\begin{array}{l}\text { Saya akan membeli kembali produk smartphone "X" di masa yang akan } \\
\text { datang. }\end{array}$ & 0.000 & $<0.05$, Valid \\
\hline CL2 & $\begin{array}{l}\text { Saya akan membicarakan hal-hal yang positif tentang smartphone"X" } \\
\text { kepada teman-teman dan kerabat saya. }\end{array}$ & 0.000 & $<0.05$, Valid \\
\hline CL3 & $\begin{array}{l}\text { Saya akan memberikan informasi yang lengkap dan tepat tentang produk } \\
\text { smartphone "X" pada saat teman-teman serta kerabat saya yang } \\
\text { membutuhkan informasi dan rekomendasi. }\end{array}$ & 0.000 & $<0.05$, Valid \\
\hline CL4 & $\begin{array}{l}\text { Saya akan mendorong teman dekat atau kerabat untuk membeli produk } \\
\text { smartphone"X". }\end{array}$ & 0.000 & $<0.05$, Valid \\
\hline
\end{tabular}


Lily Suhaily, Elias

Tabel 3. Uji Reliabilitas Variabel Public Relations, Brand Image dan Customer Loyalty

\begin{tabular}{cccc}
\hline Variabel & Cronbach's Alpha & Nof Items & Keterangan \\
\hline Public Relation & 0.748 & 4 & $>0.70$, Reliabel \\
Brand Image & 0.808 & 8 & $>0.70$, Reliabel \\
Customer Loyalty & 0.890 & 4 & $>0.70$, Reliabel \\
\hline
\end{tabular}

Tabel 4. Karateristik Responden

\begin{tabular}{|c|c|c|}
\hline No. & Karateristik R esponden & Jumlah \\
\hline \multirow[t]{4}{*}{1.} & Jenis Kelamin: & \\
\hline & a. Pria & 84 \\
\hline & b. Wanita & 76 \\
\hline & Total & 160 \\
\hline \multirow[t]{5}{*}{2.} & Usia: & \\
\hline & a.17-25 tahun & 39 \\
\hline & b. 26-35 tahun & 72 \\
\hline & c.>35 tahun & 49 \\
\hline & Total & 160 \\
\hline \multirow[t]{6}{*}{3.} & Pendidikan Terakhir & \\
\hline & a. SD-SMU & 33 \\
\hline & b. Akademi & 10 \\
\hline & c. S1 & 96 \\
\hline & d. $\quad \mathrm{S} 2$ & 21 \\
\hline & Total & 160 \\
\hline \multirow[t]{6}{*}{4.} & Pekerjaan: & \\
\hline & a.Pelajar/Mahasiswa & 32 \\
\hline & b.Ibu rumah tangga & 4 \\
\hline & c.Karyawan/Karyawati & 99 \\
\hline & d.Wiraswasta & 25 \\
\hline & Total & 160 \\
\hline \multirow[t]{7}{*}{5.} & Pengeluaran per bulan: & \\
\hline & a. $\quad<\operatorname{Rp} 2.500 .000,00$ & 23 \\
\hline & b. $\quad \mathrm{RP} 2.500 .000,00-\mathrm{RP}$ & 52 \\
\hline & $3.500 .000,00$ & 53 \\
\hline & $\begin{array}{l}\text { c. } \mathrm{RP} 3.500 .001,00-\mathrm{RP} \\
5.000 .000 .00\end{array}$ & 32 \\
\hline & d. > RP 5.000.000,00 & \\
\hline & Total & 160 \\
\hline
\end{tabular}

Sumber: Kuesioner

pendidikan terakhir S1, pekerjaan sebagai karyawan atau karyawati, pengeluaran per bulan respoden antara RP 3.500.000,00 - RP 5.000.000,00.

Uji Asumsi Klasik

\section{Uji Multikolonieritas}

\section{Tabel 5. Uji Multikolonieritas}

\section{Coefficients}

\begin{tabular}{|c|c|c|c|c|c|c|c|c|}
\hline \multirow{2}{*}{\multicolumn{2}{|c|}{ Model }} & \multicolumn{2}{|c|}{$\begin{array}{l}\text { Unstanda rd ized } \\
\text { Coeffi cients }\end{array}$} & \multirow{2}{*}{$\begin{array}{c}\text { Standardized } \\
\text { Coefficie nts } \\
\text { Beta }\end{array}$} & \multirow[b]{2}{*}{$\mathrm{t}$} & \multirow[b]{2}{*}{ Sig. } & \multicolumn{2}{|c|}{ Collinearity Statistics } \\
\hline & & B & Std. Error & & & & Tole ra nce & VIF \\
\hline \multirow[t]{3}{*}{1} & (Constant) & 1.340 & .202 & & 6.650 & .000 & & \\
\hline & Public Relatio & .190 & .099 & .195 & 1.929 & .056 & .287 & 3.478 \\
\hline & Brand Image & .596 & .108 & .561 & 5.536 & .000 & .287 & 3.478 \\
\hline
\end{tabular}

a. Dependent Variable: Customer Loyalty
Multikoloniertas menunjukkan adanya hubungan antara variabel bebas dalam model regresi. Model regresi yang baik tidak menunjukkan gejala multikolonieritas. Dari tabel 5, hasil perhitungan nilai tolerance menunjukkan tidak ada variabel independen yang memiliki nilai tolerance mendekati 1 yang berarti tidak ada korelasi antar variabel independen yang nilainya lebih dari 95\%. Hasil perhitungan nilai Variance Inflation Factor (VIF) juga menunjukkan hal yang sama, tidak ada satu variabel independen yang memiliki nilai VIF lebih dari 10. Jadi dapat disimpulkan bahwa tidak ada multikolonieritas antar variabel independen dalam model regresi (Ghozali, 2011:105).

\section{Uji Heteroskedastisitas}

Dasar pengambilan keputusan dilihat jika nilai signifikansi $<0.05$ maka dapat disimpulkan terjadi Heterokedastisitas. Dan jika nilai signifikansi $>0.05$ maka dapat disimpulkan tidak terjadi heterokedastisitas. Dari tabel diatas terlihat bahwa nilai signifikansi lebih besar dari 0.05, dapat disimpulkan bahwa tidak terjadi heterokedastisitas pada model regresi.

\section{Uji Normalitas}

Uji normalitas dengan grafik dapat menyesatkan kalau tidak hati-hati secara visual kelihatan normal, padahal secara statistik bisa sebaliknya (Ghozali, 2011: 163). Oleh sebab itu, disajikan uji statistic non parametrik Kolmogorov-Smirnov (K-S). Besarnya nilai Kolmogorov-Smirnov adalah 1.102 dengan nilai signifikansi 0.176. Dapat disimpulkan bahwa data terdistribusi dengan normal karena nilai asymp.Sig.(2tailed) lebih besar dari 0.05 . 
Tabel 6. Uji Heterokedastisitas

\begin{tabular}{|c|c|c|c|c|c|c|}
\hline \multicolumn{7}{|c|}{ Coefficients $^{a}$} \\
\hline & \multirow[t]{2}{*}{ Model } & \multicolumn{2}{|c|}{ Unstandardized Coefficients } & \multirow{2}{*}{$\begin{array}{c}\begin{array}{c}\text { Standardized } \\
\text { Coefficients }\end{array} \\
\text { Beta } \\
\end{array}$} & \multirow[t]{2}{*}{$\mathbf{t}$} & \multirow[t]{2}{*}{ Sig. } \\
\hline & & B & Std. Error & & & \\
\hline \multirow[t]{4}{*}{1} & (Constant) & -.887 & 1.246 & & -.712 & .477 \\
\hline & $\ln x 1$ & -2.524 & 1.512 & -.257 & -1.670 & .097 \\
\hline & $\ln \times 2$ & .985 & 1.818 & .090 & .542 & .589 \\
\hline & $\ln \times 3$ & -.147 & 1.375 & -.013 & -.107 & .915 \\
\hline
\end{tabular}

a. Dependent Variable: Lnei2

Tabel 7. Uii Normalitas (Kolmogorov-Smirnov)

One-Samp le Kolmogorov-Smirnov Test

\begin{tabular}{|c|c|c|c|}
\hline & & & $\begin{array}{l}\text { Unstandardiz } \\
\text { ed Residual }\end{array}$ \\
\hline $\mathrm{N}$ & & & 160 \\
\hline Normal Parameters & $a, b$ & Mean & .0000000 \\
\hline & & Std. Deviation & .46089494 \\
\hline Most Extreme & & Absolute & .087 \\
\hline Differences & & Positive & .042 \\
\hline & & Negative & -.087 \\
\hline Kolmogorov-Smirno & & & 1.102 \\
\hline Asymp. Sig. (2-tailec & & & .176 \\
\hline
\end{tabular}

a. Test distribution is Normal.

b. Calculated from data.

\section{Uji Regresi Moderasi (Moderated Regression} Analysis)

Model regresi moderasi digunakan dalam penelitian ini untuk menguji pengaruh public relation terhadap customer loyalty yang dimoderasi oleh brand image.

Persamaan regresi (1): Pengaruh variabel public relation terhadap customer loyalty.

Tabel 8. Model Summarv Persamaan Regresi (1)

\begin{tabular}{|l|r|r|r|r|}
\multicolumn{8}{c|}{ Model Summary } \\
\hline Model & R & R Square & $\begin{array}{c}\text { Adju sted } \\
\text { R Square }\end{array}$ & $\begin{array}{c}\text { Std. Error of } \\
\text { the Estim ate }\end{array}$ \\
\hline 1 & $.668^{\mathrm{a}}$ & .447 & .443 & .50547 \\
\hline
\end{tabular}

a. Predictors: (Constant), Public Relation

Berdasarkan tabel model summary di atas, menunjukkan nilai R Square cukup tinggi yaitu $44.7 \%$ yang berarti variabilitas customer loyalty yang dapat dijelaskan oleh public relation sekitar $44.7 \%$ dan sisanya $55.3 \%$ dijelaskan oleh variabel lain diluar model ini.
Hasil ANOVA atau $\mathrm{F}$ test menunjukkan nilai $\mathrm{F}$ hitung sebesar 126.651 dengan tingkat signifikansi 0.000 jauh dibawah 0.1. Hal ini menunjukkan bahwa variabel public relation secara signifikan berpengaruh terhadap customer loyalty.

Hasil dari tabel 10 koefisien menunjukkan variabel public relation memberikan nilai koefisien 0.652 dan nilai p-value public relation pada kolom significant menunjukkan hasil 0.000. Nilai p-value ini lebih kecil dari nilai $\alpha=0.1$ sehingga dapat disimpulkan public relation signifikan terhadap customer loyalty.

Persamaan regresi (2): Pengaruh variabel public relation dan brand image terhadap customer loyalty.

Berdasarkan tabel 11 model summary, menunjukkan nilai R Square cukup tinggi yaitu $53.7 \%$ yang berarti variabilitas customer loyalty yang dapat dijelaskan oleh public relation dan brand image adalah sekitar $53.7 \%$ dan sisanya $46.3 \%$ dijelaskan oleh variabel lain diluar model ini.

Hasil ANOVA atau $\mathrm{F}$ test menunjukkan nilai $F_{\text {hitung }}$ sebesar 91.128 dengan tingkat signifikansi 0.000 jauh dibawah 0.1. Dapat disimpulkan bahwa variabel 
Lily Suhaily, Elias

Tabel 9. ANOVA Persamaan Regresi (1)

ANO VA ${ }^{b}$

\begin{tabular}{|ll|r|r|r|r|r|}
\hline \multicolumn{1}{|c|}{ Mo del } & \multicolumn{1}{c|}{$\begin{array}{c}\text { Sum of } \\
\text { Squares }\end{array}$} & $\mathrm{df}$ & Mean Square & \multicolumn{1}{c|}{$\mathrm{F}$} & Sig. \\
\hline 1 & Regression & 32.615 & 1 & 32.615 & 127.651 & $.000^{\mathrm{a}}$ \\
& Re sidual & 40.369 & 158 & .256 & & \\
& Total & 72.984 & 159 & & & \\
\hline
\end{tabular}

a. Predictors: (Constant), Public Relation

b. Dependent Variable: Custom er Loyalty

Tahel 10. Koefisien Persamaan Regresi (1)

Coeffic ients ${ }^{a}$

\begin{tabular}{|c|c|c|c|c|c|c|}
\hline \multirow{2}{*}{\multicolumn{2}{|c|}{ Model }} & \multicolumn{2}{|c|}{$\begin{array}{c}\text { Unstandar dized } \\
\text { Coefficients }\end{array}$} & \multirow{2}{*}{$\begin{array}{l}\text { Stand ardized } \\
\text { Coefficients } \\
\text { Beta }\end{array}$} & \multirow[b]{2}{*}{$\mathrm{t}$} & \multirow[b]{2}{*}{ Sig. } \\
\hline & & $\mathrm{B}$ & Std. Error & & & \\
\hline \multirow[t]{2}{*}{1} & (C onstant) & 1.761 & .203 & & 8.652 & .000 \\
\hline & Public Relation & .652 & .058 & .668 & 11.298 & .000 \\
\hline
\end{tabular}

a. Dependent Variable: Customer Loyalty

Tabel 11. Model Summary Persamaan Regresi (2)

\section{Model Summary}

\begin{tabular}{|l|r|r|r|r|r|}
\hline Model & $\mathrm{R}$ & $\mathrm{R}$ Square & $\begin{array}{c}\text { Adjusted } \\
\text { R Square }\end{array}$ & $\begin{array}{c}\text { Std. Error of } \\
\text { the Estimate }\end{array}$ & $\begin{array}{c}\text { Durbin- } \\
\text { Watson }\end{array}$ \\
\hline 1 & $.733^{\mathrm{a}}$ & .537 & .531 & .46382 & 1.961 \\
\hline
\end{tabular}

a. Predictors: (Constant), B rand Image, Public Relation

b. Dependent Variable: Customer Lo yalty

Tabel 12. ANOVA Persamaan Regresi (2)

ANOVAb

\begin{tabular}{|rl|r|r|r|r|r|}
\hline Model & & $\begin{array}{c}\text { Sum of } \\
\text { Squares }\end{array}$ & $\mathrm{df}$ & Mean Square & \multicolumn{1}{c|}{$\mathrm{F}$} & Sig. \\
\hline 1 & Regression & 39.209 & 2 & 19.604 & 91.128 & $.000^{\mathrm{a}}$ \\
& R esidual & 33.775 & 157 & .215 & & \\
& Total & 72.984 & 159 & & & \\
\hline
\end{tabular}

a. Pred ictors: (Constant), Brand Image, Public Relation

b. D ependent Variable: Cus tome $r$ Loya tty

public relation dan brand image secara signifikan berpengaruh terhadap customer loyalty.

Tabel 13. KoefisienPersamaan Regresi (2)

$$
\text { Coefficien th }
$$

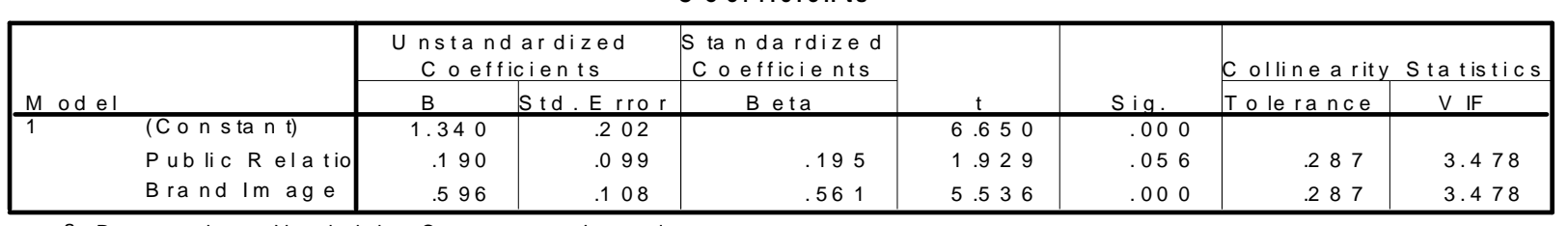

a. D ependent Variable:C ustom er Loyalty

Hasil dari tabel 13 koefisien, variabel public relation memberikan nilai koefisien 0.190 dan nilai 
p-value public relation pada kolom significant menunjukkan hasil 0.056. Variabel brand image memberikan nilai koefisien 0.596 dan nilai p-value brand image pada kolom significant menunjukkan hasil 0.000 . Nilai $p$-value lebih kecil dari nilai $\alpha=0.1$ sehingga dapat disimpulkan bahwa public relation dan brand image berpengaruh signifikan terhadap customer loyalty.

Persamaan regresi (3): Pengaruh variabel public relation terhadap customer loyalty yang dimoderasi oleh brand image.
Hasil dari tabel koefisien diatas, menunjukkan variabel public relation memberikan nilai koefisien 1.026 dan nilai $\mathrm{p}$-value public relation pada kolom significant menunjukkan hasil 0.048 . Variabel interaksi memberikan nilai koefisien -0.272 dan nilai pvalue menunjukkan hasil 0.000. nilai p-value ini lebih kecil dari nilai $\alpha=0.1$ sehingga dapat disimpulkan public relation yang dimoderasi oleh brand image berpengaruh signifikan terhadap customer loyalty.

\section{Tabel 14. Model Summary Persamaan Regresi (3)}

\begin{tabular}{|c|c|c|c|c|c|}
\hline $\mathrm{M}$ od el & $\mathrm{R}$ & R Square & $\begin{array}{l}\text { A d justed } \\
\text { R Square }\end{array}$ & $\begin{array}{l}\text { Std. Error of } \\
\text { the Estim ate }\end{array}$ & $\begin{array}{l}\text { Durbin- } \\
\text { W atson }\end{array}$ \\
\hline 1 & $.761 \mathrm{a}$ & .579 & .571 & .44359 & 2.067 \\
\hline
\end{tabular}

Tabel 15. ANOVA Persamaan Regresi (3)

$A N O A^{b}$

\begin{tabular}{|cl|r|r|r|r|r|}
\hline Model & & $\begin{array}{c}\text { Sum of } \\
\text { Squares }\end{array}$ & df & Mean Square & F & Sig. \\
\hline 1 & Regression & 42.288 & 3 & 14.096 & 71.637 & $.000^{\mathrm{a}}$ \\
& Residual & 30.696 & 156 & .197 & & \\
& Total & 72.984 & 159 & & & \\
\hline
\end{tabular}

a. Predictors: (Constant), Interaksi, Public Re lation, B rand Image

b. De pendent V ariable: Custom er Loyalty

Berdasarkan tabel model summary di atas, menunjukkan nilai $R$ square cukup tinggi yaitu $57.9 \%$ yang berarti variabilitas customer loyalty yang dapat dijelaskan oleh public relation yang dimoderasi oleh brand image sekitar $57.9 \%$ dan sisanya $42.1 \%$ dijelaskan oleh variabel lain di luar model ini.

Hasil ANOVA atau F test menunjukkan nilai $F_{\text {hitung }}$ sebesar 71.637 dengan tingkat signifikansi 0.000 jauh di bawah 0.1. Dapat disimpulkan bahwa variabel public relation yang dimoderasi oleh brand image secara signifikan berpengaruh terhadap customer loyalty.

Tabel 16. KoefisienPersamaan Regresi (3)
Hasil analisis moderasi dari persamaan regresi (1), (2), dan (3)

Dari hasil ketiga persamaan regresi diatas,maka dapat disimpulkan ke dalam tiga persamaan berikut: $\mathrm{Yi}=\alpha+\beta 1 \mathrm{X} 1+\varepsilon$

Customer Loyalty $=1.761+0.652$ public relation

Nilai $\mathrm{t}=(8.652)(11.298)$

$\mathrm{R} 2 \mathrm{Adj}=0.447$

$\mathrm{Yi}=\alpha+\beta 1 \mathrm{Xi}+\beta 2 \mathrm{Zi}+\varepsilon$

Customer Loyalty $=$

$1.340+0.190$ public relation +0.596 brand image Nilai $=(6.650)(1.929)(5.536)$

\section{Coeffic ien ts}

\begin{tabular}{|c|c|c|c|c|c|c|c|c|}
\hline \multirow{2}{*}{\multicolumn{2}{|c|}{ Model }} & \multicolumn{2}{|c|}{$\begin{array}{c}\text { Unstand a rdized } \\
\text { Coefficients }\end{array}$} & \multirow{2}{*}{$\begin{array}{c}\begin{array}{c}\text { Standardiz ed } \\
\text { Coefficients }\end{array} \\
\text { Beta }\end{array}$} & \multirow[b]{2}{*}{$\mathrm{t}$} & \multirow[b]{2}{*}{ Sig. } & \multicolumn{2}{|c|}{ Collin e arity $S$ ta tis tics } \\
\hline & & B & Std. Error & & & & Tole rance & V IF \\
\hline \multirow[t]{4}{*}{1} & (Constant) & -1.511 & .746 & & -2.025 & .045 & & \\
\hline & Public Relatio & 1.026 & .231 & 1.052 & 4.435 & .000 & .048 & 20.886 \\
\hline & B rand Image & 1.546 & .261 & 1.455 & 5.916 & .000 & .045 & 22.432 \\
\hline & In teraks i & -.272 & .069 & -1.694 & -3.956 & .000 & .015 & 68.026 \\
\hline
\end{tabular}

a. Dependent Variable: $\mathrm{C}$ us tom er Loyalty 
R2 Adj $=0.537$

$\mathrm{Yi}=\alpha+\beta 1 \mathrm{X} 1+\beta 2 \mathrm{Z} 1+\beta 3 \mathrm{Xi} * \mathrm{Zi}+\varepsilon \ldots \ldots \ldots \ldots . .(3)$

Customer Loyalty $=$

$-1.511+1.026$ public relation +1.546 brand image

-0.272 public relation $*$ Brand image

Nilai $\mathrm{t}=(-2.025)(4.435)(5.916)(-3.956)$

R2 Adj $=0.571$

Dengan membandingkan ketiga regresi ini diperoleh informasi bahwa $\beta 2 \neq 0$ (signifikan) dan $\beta 3 \neq$ 0 (signifikan) maka dapat disimpulkan bahwa variabel brand image merupakan variabel quasi moderator.

\section{Uji Residual}

Analisis residual ingin menguji pengaruh deviasi (penyimpangan) dari suatu model yang berfokus pada lack of fit (ketidakcocokan) yang dihasilkan dari penyimpangan hubungan linier antara variabel independen yaitu public relation dan citra merek. Langkah uji residual dapat dikembangkan dengan persamaan regresi sebagai berikut:

Brand image $=\mathrm{a}+\mathrm{b} 1$ public relation $+\mathrm{e}$

$|\mathrm{e}|=\mathrm{a}+\mathrm{b} 1$ customer loyalty.

Persamaan regresi (2) menggambarkan apakah variabel brand image merupakan variabel moderasi dan ini ditunjukan dengan nilai koefisien b1 customer loyalty signifikan dan negatif hasilnya (yang dapat disimpulkan adanya lack of fit antara public relation dan brand image mengakibatkan keputusan pembelian turun atau berpengaruh negatif. tidak begitu berbeda jauh yaitu jumlah responden pria adalah $52.5 \%$ dan jumlah responden wanita adalah 47.5\%. Mayoritas responden berusia 26-35 tahun sebesar $45 \%$, berpendidikan terakhir yaitu S1 sebesar $60 \%$, jenis pekerjaan responden saat ini adalah karyawan atau karyawati yaitu sebesar $61.9 \%$ serta pengeluaran per bulan respoden adalah $\mathrm{Rp} 3.500 .000,00$ Rp 5.000.000,00 yaitu sebesar 33.1\%.

Berdasarkan data tersebut, penulis menyimpulkan bahwa baik responden pria maupun wanita menggunakan smartphone "X". Mayoritas responden berusia 26-35 tahun dan berpendidikan terakhir S1, sehingga dapat disimpulkan bahwa konsumen yang berusia muda dengan

Berdasarkan hasil analisis model regresi moderasi (moderated regression analysis), dapat disimpulkan bahwa public relation berpengaruh terhadap customer loyalty secara tidak langsung yang dimoderasi oleh brand image. Dari hasil di atas dapat disimpulkan bahwa brand image terbukti memperkuat hubungan antara public relation terhadap customer loyalty karena pada tabel koefisien menunjukkan hasil yang signifikan. Variabel customer loyalty yang dapat dijelaskan oleh public relation yang dimoderasi oleh brand image adalah sebesar $57.9 \%$ dan sisanya 42.1\% dijelaskan oleh variabel lain seperti customer satisfaction. Sedangkan variabel customer loyalty yang dapat dijelaskan oleh public relation sebesar 44.7\% dan sisanya $55.3 \%$ dijelaskan oleh variabel

\section{Tabel 17. Tabel Residual}

\section{Coefficie $n t^{a}$}

\begin{tabular}{|c|c|c|c|c|c|}
\hline \multirow[b]{2}{*}{ Model } & \multicolumn{2}{|c|}{$\begin{array}{c}\text { Unstanda rdized } \\
\text { Coefficients }\end{array}$} & \multirow{2}{*}{$\begin{array}{l}\text { Standardized } \\
\text { Coefficie nts } \\
\text { Beta }\end{array}$} & \multirow[b]{2}{*}{$t$} & \multirow[b]{2}{*}{ Sig. } \\
\hline & $\mathrm{B}$ & Std. Error & & & \\
\hline $\begin{array}{l}\text { (Constant) } \\
\text { Cus to mer Lo yalt y }\end{array}$ & $\begin{array}{r}.605 \\
-.065\end{array}$ & $\begin{array}{l}.128 \\
.031\end{array}$ & -.162 & $\begin{array}{r}4.722 \\
-2.064\end{array}$ & $\begin{array}{l}.000 \\
.041\end{array}$ \\
\hline
\end{tabular}

a. D epend ent $V$ a riable: absres 1

Berdasarkan tabel di atas, dapat disimpulkan bahwa jelas variabel customer loyalty signifikan karena nilai p-value 0.031 kurang dari 0.05 dan parameternya negatif yaitu -0.162. dan dapat disimpulkan juga bahwa variabel brand image merupakan variabel moderasi. Brand image dikatakan sebagai variabel moderasi apabila nilai koefisien parameternya negatif dan signifikan.

\section{PEMBAHASAN}

Hasil penelitian dapat menjelaskan bahwa baik responden pria maupun wanita memiliki jumlah yang lain diluar model ini seperti product quality, service quality. Hasil penelitian ini menunjukkan pengaruh secara tidak langsung (dimoderasi oleh brand image) dari public relation terhadap customer loyalty lebih besar daripada pengaruh langsung oleh brand image dimana nilai $\mathrm{R}$ square dari pengaruh langsung adalah $53.7 \%$.

Kesimpulan dari seluruh hasil pengujian menunjukkan bahwa public relation berpengaruh baik secara langsung maupun secara tidak langsung di dalam penelitian ini. Public relation, brand image, dan customer loyalty mempunyai korelasi yang kuat. 
Berarti public relation dapat membuat image konsumen terhadap smartphone " $X$ " baik dan dengan baiknya image tersebut konsumen akan menjadi loyal.

Uji residual menunjukkan hasil bahwa brand image mampu memoderasi public relation terhadap customer loyalty. Hal ini dapat menunjukkan bahwa public relation dari smartphone Samsung Galaxy yang baik dapat membangun brand image yang menciptakan loyalitas konsumen terhadap smartphone "X".

Penelitian terdahulu yang dilakukan oleh An-Tien Hsieh dan Li (2008), di mana penelitiannya juga melihat pengaruh brand image yang memoderasi public relation perception terhadap customer loyalty dalam perusahaan asuransi di mana ini merupakan perusahaan jasa, dan hasil dari penelitian ini juga menunjukkan hasil yang positif antara public relation perception terhadap loyalitas konsumen yang dimoderasi oleh brand image. Dan dalam jurnal Koubaa (2008) yang berjudul "Country of Origin, Brand Image perception, and Brand Image Structure" menjelaskan bahwa brand image punya peran yang penting dalam proses pemasaran produk di setiap negara. Dan dalam penelitian ini juga menunjukan bahwa variabel brand image pada smartphone Samsung menjadi variabel yang memoderasi public relation terhadap customer loyalty karena brand image yang baik dan sesuai target mendorong konsumen untuk lebih loyal terhadap produk smartphone Samsung.

\section{KESIMPULAN}

Hasil penelitian ini menunjukkan pengaruh secara tidak langsung (dimoderasi oleh brand image) dari public relation terhadap customer loyalty lebih besar daripada pengaruh langsung oleh brand image di mana nilai $R$ square dari pengaruh langsung adalah $53.7 \%$. Hal ini karena tidak hanya brand image saja yang dapat berpengaruh terhadap loyalitas konsumen, tapi varibel lain seperti kepuasan juga dapat mempengaruhi loyalitas konsumen.
Terdapat pengaruh public relation terhadap customer loyalty yangdimoderasi oleh brand image pada produk smartphone merek "X". Berarti public relation dapat membuat image konsumen terhadap smartphone "X" baik dan dengan baiknya image tersebut konsumen akan menjadi loyal.

\section{DAFTAR RUJUKAN}

An-Tien, H., \& Chung-Kai, L. 2007.The Moderating Effect of Brand Image on Public Relations Perception and Customer Loyalty. Journal of Marketing Intelligence and planning, Vol 26,no.1. 2008:26-38.

Griffin, J. alih bahasa: Dr. Dwi Kartini Yahya. 2003. Customer Loyalty, edisi revisi cetakan terbaru. Ciracas: Erlangga

Hair, J., W. Black, B. Babin, R.A., and R. Tatham. 2006. Multivariate Data Analysis. New Jersey: Prentice Hall.

Imam, G. 2011. Aplikasi Analisis Multivari- ate Dengan Program IBM SPSS 19. Semarang: BP Universitas Diponegoro.

Kotabe, M., and Helsen, K. 2011. Global Marketing Manajement. 5 ed., John Wiley \& Sons (Asia) Pte Ltd.

Kotler, P., and Keller, K., Lane. alih bahasa: Benyamin M. 2008. Manajemen Pemasaran.12nd ed. Indeks.

Kouba, Y. 2007,Country Origin,Brand Image Perception, and Brand Image Structure. Asia Pacific Journal of Marketing and Logistics, Vol 20, No. 2. 2008:139155.

Nickels \& McHugh, alih bahasa: Adi Maulana, 2008. Manajemen Pemasaran, Cetakan Ketujuh. Jakarta: Rajagrafindo Persada.

Nunnally, J.C. 1978. Psychometric Theory. Mc. Graw Hill Book Company.

Rangkuti. 2008. Manajemen Pemasaran: Analisis Perilaku Konsumen, Edisi Pertama, Cetakan Keempat. Yogyakarta: BPFE.

S. Uyanto. 2006. Stanislaus, Pedoman Analisis Data dengan SPSS, edisi kedua, Yogyakarta: Penerbit Graha Ilmu. 